\title{
Influence of Zn Addition on Aging Response and Corrosion Resistance of Mg-Gd-Nd-Zr Alloy
}

\author{
B. K. Park ${ }^{1}$, J. H. Jun ${ }^{1}$ and J. M. Kim ${ }^{2}$ \\ ${ }^{1}$ Advanced Materials Division, Korea Institute of Industrial Technology, Incheon 406-840, Korea \\ ${ }^{2}$ Division of Advanced Materials Engineering, Hanbat National University, Daejeon 305-709, Korea
}

\begin{abstract}
The age hardening response and corrosion resistance of $\mathrm{Mg}-8 \% \mathrm{Gd}-2 \% \mathrm{Nd}-0.3 \% \mathrm{Zr}$ alloys with various $\mathrm{Zn}$ contents up to $2 \%$ (in weight) have been investigated. The $\mathrm{Zn}$-free alloy exhibits relatively lower age hardening and slower age response, whereas the addition of $\mathrm{Zn}$ enhances the age hardening response remarkably. The weight loss after salt spray test decreases with increasing $\mathrm{Zn}$ content in the peak-aged alloys, which is presumably associated with the increased amount of eutectic Mg-Zn-Nd-Gd phase acting as a corrosion barrier along the $\alpha$ grain boundaries. The potentiodynamic polarization curves reveal that with the increase in $\mathrm{Zn}$ content, the value of $I_{\text {corr }}$ decreases gradually while the value of $E_{\text {corr }}$ increases. [doi:10.2320/matertrans.MC200743]
\end{abstract}

(Received October 5, 2007; Accepted March 13, 2008; Published April 16, 2008)

Keywords: magnesium-gadolinium, polarization curve, salt spray test, corrosion resistance

\section{Introduction}

Magnesium (Mg) alloys have gained increasing attention due to many superior characteristics and their demands on many applications such as automobile parts and mobile IT products. However, low mechanical properties of $\mathrm{Mg}$ alloys at elevated temperatures and relatively poor corrosion resistance have retarded their wider utilization. ${ }^{1,2)}$ Therefore, one of current critical aims for alloy development is to enhance both elevated temperature properties and corrosion resistance so that their application can be more diverse. ${ }^{3-5)}$ The additions of heavy metal rare-earth (RE) elements such as $\mathrm{Y}, \mathrm{Gd}, \mathrm{Dy}, \mathrm{Tb}$ and $\mathrm{Nd}$ to $\mathrm{Mg}$ alloy have been known to bring excellent tensile and creep properties as well as corrosion resistance after proper peak-aging treatment. ${ }^{5-10)}$

Recently, it was found that Zn plays a beneficial role in accelerating age hardening response and increasing peak strength for binary $\mathrm{Mg}$ alloys containing RE elements, $\mathrm{Sn}$ or $\mathrm{Ca}$ because the $\mathrm{Zn}$ addition gives rise to uniform and dense distribution of basal precipitates. ${ }^{11,12)}$ In spite of many works on role of $\mathrm{Zn}$ in microstructure and mechanical properties up to date, ${ }^{13-20)}$ the effect of $\mathrm{Zn}$ addition on the corrosion resistance of $\mathrm{Mg}-\mathrm{RE}$ based alloys has been rarely investigated. In this study, the variations in age hardening response and corrosion resistance with $\mathrm{Zn}$ content were investigated and discussed for $\mathrm{Mg}-8 \% \mathrm{Gd}-2 \% \mathrm{Nd}-0.3 \% \mathrm{Zr}-$ $(0 \sim 2) \% \mathrm{Zn}$ alloys.

\section{Experimental}

Four $\mathrm{Mg}-8 \% \mathrm{Gd}-2 \% \mathrm{Nd}-0.3 \% \mathrm{Zr}-(0,0.5,1$ and 2$) \% \mathrm{Zn}$ (in weight) alloys were melted in a steel crucible under the protection of $\left(\mathrm{SF}_{6}+\mathrm{CO}_{2}\right)$ mixed gas and poured into the metallic mold that was preheated to $200^{\circ} \mathrm{C}$. The chemical compositions of experimental alloys are listed in Table 1. The alloy ingots were cut into small pieces and solutiontreated at $530^{\circ}$ for $6 \mathrm{hrs}$, followed by a water quench at $80^{\circ} \mathrm{C}$ and aging at $220^{\circ} \mathrm{C}$ up to $72 \mathrm{hrs}$. In order to investigate the aging response characteristics, the micro-hardness of solution-treated and aged specimens was measured by using
Table 1 Chemical compositions of alloys used in this study (mass\%).

\begin{tabular}{cccccc}
\hline Alloys & $\mathrm{Gd}$ & $\mathrm{Nd}$ & $\mathrm{Zr}$ & $\mathrm{Zn}$ & $\mathrm{Mg}$ \\
\hline $\mathrm{Mg}-8 \% \mathrm{Gd}-2 \% \mathrm{Nd}-0.3 \% \mathrm{Zr}$ & 7.41 & 1.79 & 0.32 & - & Bal. \\
\hline $\mathrm{Mg}-8 \% \mathrm{Gd}-2 \% \mathrm{Nd}-0.3 \% \mathrm{Zr}-0.5 \% \mathrm{Zn}$ & 7.65 & 1.94 & 0.32 & 0.52 & Bal. \\
\hline $\mathrm{Mg}-8 \% \mathrm{Gd}-2 \% \mathrm{Nd}-0.3 \% \mathrm{Zr}-1 \% \mathrm{Zn}$ & 7.46 & 1.93 & 0.27 & 0.83 & Bal. \\
\hline $\mathrm{Mg}-8 \% \mathrm{Gd}-2 \% \mathrm{Nd}-0.3 \% \mathrm{Zr}-2 \% \mathrm{Zn}$ & 7.53 & 1.95 & 0.27 & 1.86 & Bal. \\
\hline
\end{tabular}

a Vickers micro-hardness tester under a load of $100 \mathrm{gf}$. Microstructural examinations were carried out by means of optical microscope $(\mathrm{OM})$, field emission scanning electron microscope (FE-SEM) equipped with energy-dispersive $\mathrm{X}$-ray spectrometer (EDX) and field emission transmission electron microscope (FE-TEM) operating at $200 \mathrm{kV}$.

The salt spray test was conducted according to the ASTM B117 standard; $5 \% \mathrm{NaCl}$ solution, operation temperature of $35^{\circ} \mathrm{C}$, humidity of $95 \%$, test period of $72 \mathrm{hrs}$. The corrosion products were cleaned by a chromate acid solution of (180 g $\mathrm{CrO}_{3}+1 \mathrm{~g} \mathrm{AgNO}_{3} / \ell$ distilled water) at the ambient temperature for $5 \mathrm{~min}$, and then the weight loss was calculated. On the other hand, the polarization curves were obtained in the electrolytic cell containing $5 \% \mathrm{NaCl}$ solution during the electrochemical tests. The surface was sealed with epoxy resin except for the area of $1 \mathrm{~cm}$ diameter that was exposed for the test.

\section{Results and Discussion}

\subsection{Microstructure}

Figure 1 shows the age hardening curves of $\mathrm{Mg}-8 \% \mathrm{Gd}-$ $2 \% \mathrm{Nd}-0.3 \% \mathrm{Zr}-(0 \sim 2) \% \mathrm{Zn}$ alloys at $220^{\circ} \mathrm{C}$ after solution treatment. The $\mathrm{Mg}-8 \% \mathrm{Gd}-2 \% \mathrm{Nd}-0.3 \% \mathrm{Zr}$ alloy displayed the lowest peak hardness and the slowest age response among the experimental alloys. It is obvious that the time for peak hardness is decreased whereas the peak hardness value is increased with increasing $\mathrm{Zn}$ content. The relatively poor age response for the $\mathrm{Zn}$-free alloy would be closely related to lower volume fraction and non-uniform distribution of the 


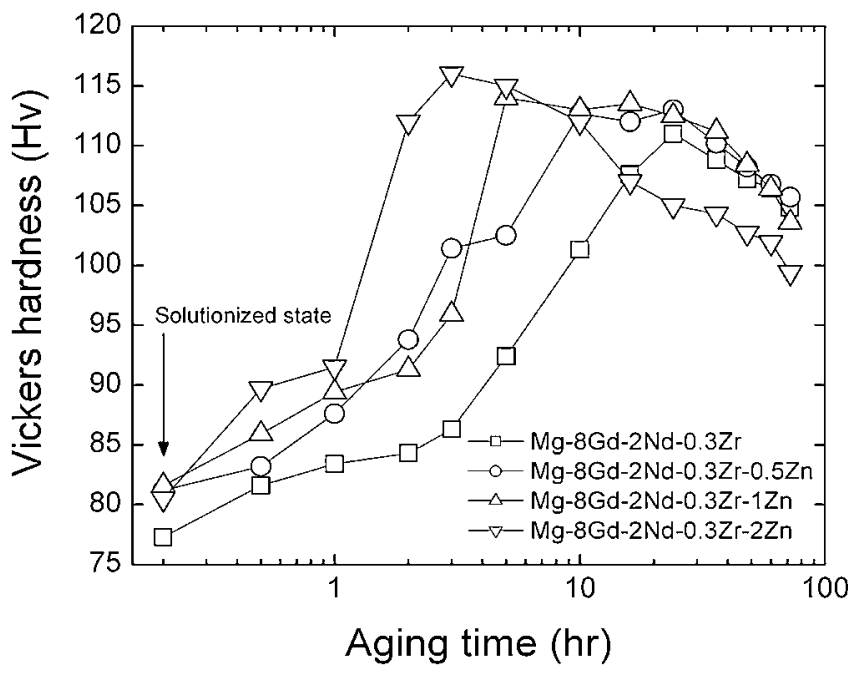

Fig. 1 Change in Vickers hardness with aging time for $\mathrm{Mg}-8 \% \mathrm{Gd}-2 \% \mathrm{Nd}-$ $0.3 \% \mathrm{Zr}-(0 \sim 2) \% \mathrm{Zn}$ alloys.

strengthening precipitates. ${ }^{11)}$ Optical microstructures of the peak-aged $\mathrm{Mg}-8 \% \mathrm{Gd}-2 \% \mathrm{Nd}-0.3 \% \mathrm{Zr}-(0 \sim 2) \% \mathrm{Zn}$ alloys are represented in Fig. 2. It can be seen that the alloys are primarily composed of $\alpha-\mathrm{Mg}$ matrix and some precipitates appear along the grain boundaries and within the grains. In view of previous reports, ${ }^{13,14)}$ the precipitates along the $\alpha$ grain boundaries may well be eutectic compounds which were not solutionized during the solution treatment and precipitates gathered within the grains are $\mathrm{Zr}$-containing particles. It is interesting to note that $\mathrm{Zn}$-free alloy does not have eutectic phase along the grain boundaries (Fig. 2(a)), while the amount of eutectic phase along the grain boundaries becomes greater with the increase in $\mathrm{Zn}$ content (Figs. 2(b)-(d)). Furthermore, the addition of $\mathrm{Zn}$ affects to decrease the grain size (average grain sizes of the alloys are measured as $148(0 \% \mathrm{Zn}), 81(0.5 \% \mathrm{Zn}), 64(1 \% \mathrm{Zn})$ and $56 \mu \mathrm{m}(2 \% \mathrm{Zn})$, respectively). Figure 3 shows the SEM images of (a) $\mathrm{Mg}-8 \% \mathrm{Gd}-2 \% \mathrm{Nd}-0.3 \% \mathrm{Zr}$ and (b) $\mathrm{Mg}-8 \% \mathrm{Gd}-$ $2 \% \mathrm{Nd}-0.3 \% \mathrm{Zr}-2 \% \mathrm{Zn}$ alloys. The EDX results indicate that the compounds observed at the grain boundaries for the Zn-free alloy (Fig. 3(a)) are Mg-Gd-Nd compound, whereas those for the $2 \% \mathrm{Zn}$-containing alloy (Fig. 3(b)) are Mg-ZnNd-Gd phase, respectively. TEM microstructures of the peak-aged $\mathrm{Zn}$-free and $2 \% \mathrm{Zn}$-containing alloys are shown in Fig. 4. The precipitates with fine lenticular morphology were identified as Mg-Gd-Nd (Fig. 4(a)) and Mg-Zn-Nd-Gd (Fig. 4(b)), respectively, as observed in Fig. 3. We did not investigate the nano-sized fine precipitates such as $\beta^{\prime \prime}, \beta^{\prime}$ or $\beta$ phase within the grains, because previous works had already been done on precipitation process which is closely related to the age hardening for these alloy systems. ${ }^{14,15)}$

\subsection{Corrosion resistance \\ 3.2.1 Salt spray test}

The corrosion rates obtained after the salt spray tests for $\mathrm{Mg}-8 \% \mathrm{Gd}-2 \% \mathrm{Nd}-0.3 \% \mathrm{Zr}-(0 \sim 2) \% \mathrm{Zn}$ alloys in $5 \% \mathrm{NaCl}$ for
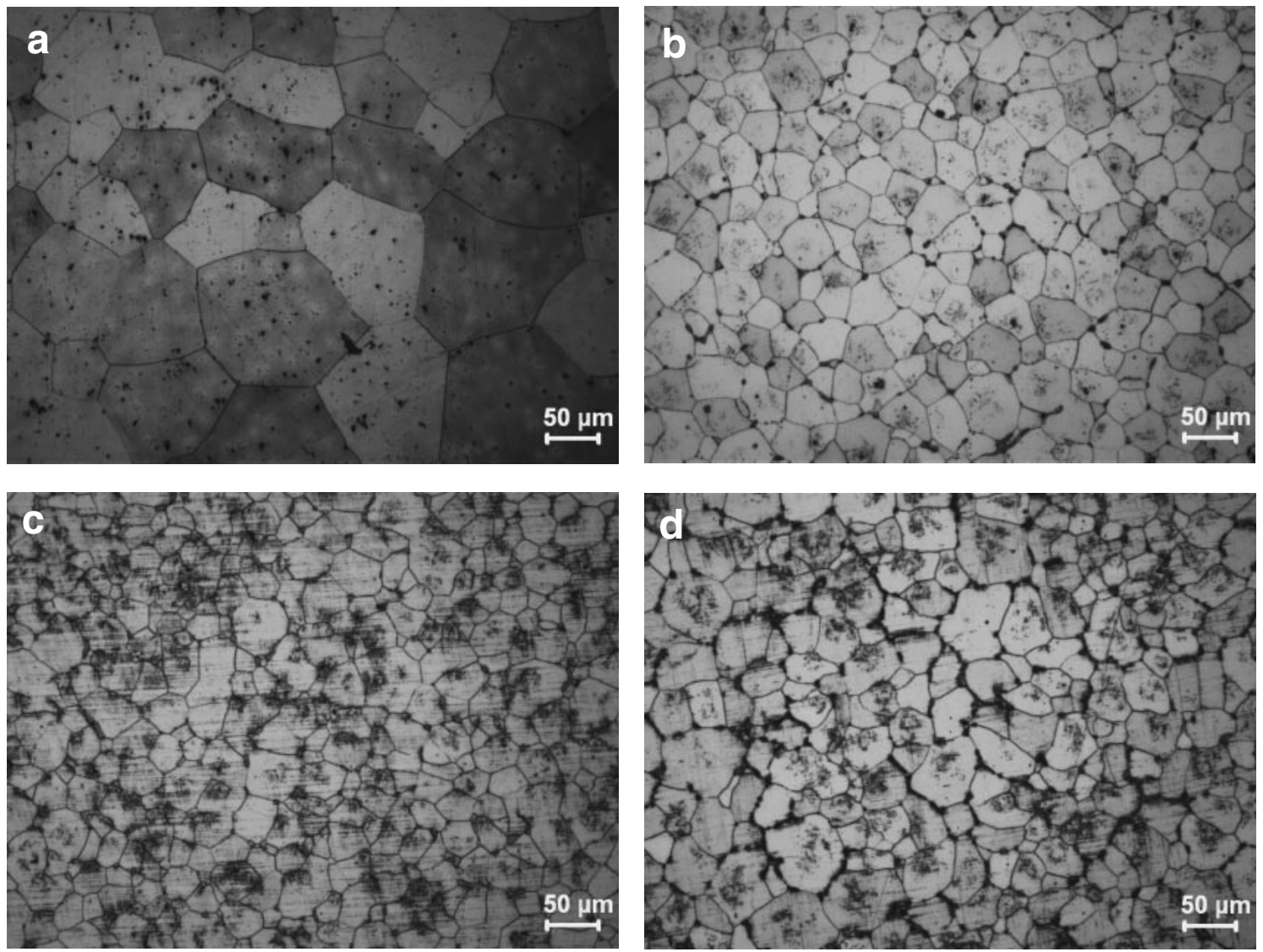

Fig. 2 Optical microstructures of peak-aged (a) Mg- $8 \%$ Gd-2\%Nd-0.3\%Zr, (b) Mg-8\%Gd-2\%Nd-0.3\%Zr- $0.5 \% \mathrm{Zn}$, (c) Mg-8\%Gd-2\%Nd$0.3 \% \mathrm{Zr}-1 \% \mathrm{Zn}$ and (d) $\mathrm{Mg}-8 \% \mathrm{Gd}-2 \% \mathrm{Nd}-0.3 \% \mathrm{Zr}-2 \% \mathrm{Zn}$ alloys. 

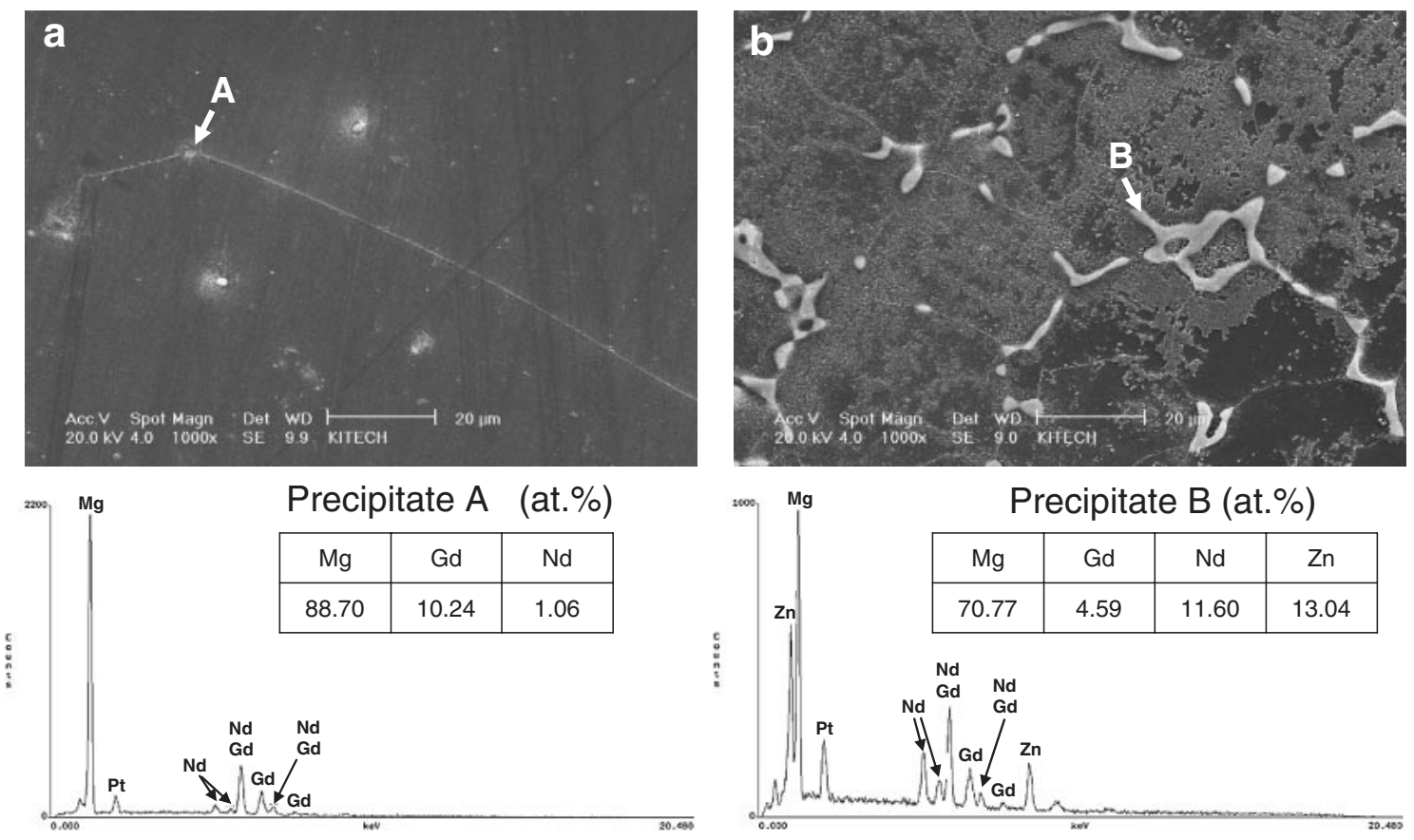

Fig. 3 SEM images and EDX spectrum on the precipitates located at grain boundaries for peak-aged (a) Mg- $8 \% \mathrm{Gd}-2 \% \mathrm{Nd}-0.3 \% \mathrm{Zr}$ and (b) $\mathrm{Mg}-8 \% \mathrm{Gd}-2 \% \mathrm{Nd}-0.3 \% \mathrm{Zr}-2 \% \mathrm{Zn}$ alloys.
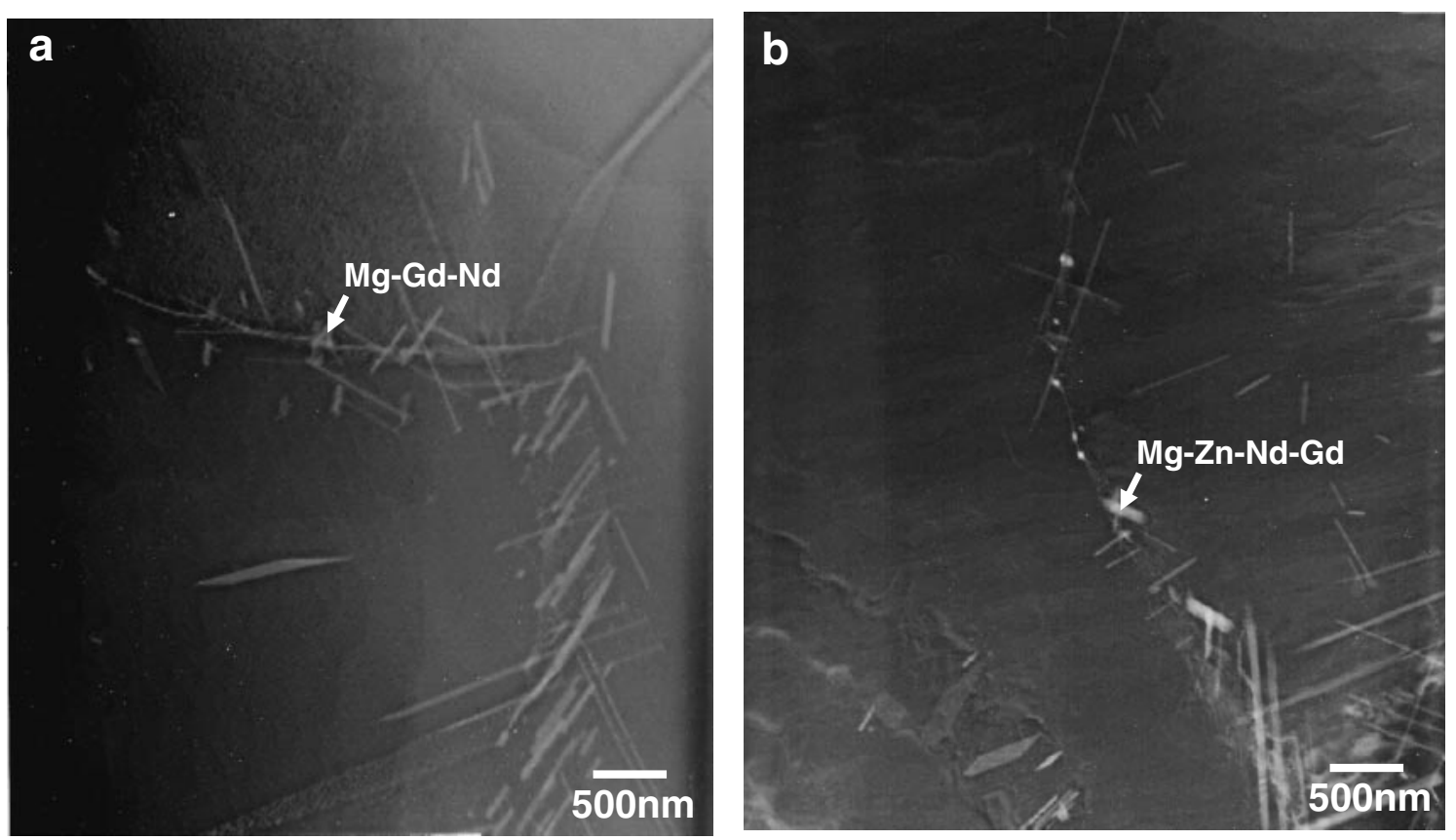

Fig. 4 TEM images of peak-aged (a) Mg-8\%Gd-2\%Nd-0.3\% Zr and (b) Mg-8\%Gd-2\%Nd-0.3\%Zr-2\%Zn alloys.

$72 \mathrm{hrs}$ are given in Fig. 5. It is noteworthy that the corrosion rate decreases continuously from 3.94 to $1.53 \mathrm{mg} / \mathrm{cm}^{2} /$ day by the addition of $\mathrm{Zn}$ up to $2 \%$. The cross sectional microstructures of the corroded surface after the salt spray tests are represented in Fig. 6. All the investigated alloys exhibit corrosion pits along the grain boundaries. As observed in Fig. 6, the corrosion pits of $\mathrm{Zn}$-free alloy are apparently larger and deeper than other Zn-containing alloys. Song et al. reported that in the case of AZ91 alloy, higher $\beta$ fraction, usually formed along the grain boundaries, and more continuous manner of $\beta$ phase in response to finer $\alpha$ grains would give rise to better corrosion resistance of the alloy, because $\beta$ networks can act as a corrosion barrier. ${ }^{21)}$ Considering the previous report ${ }^{21)}$ and Figs. 2, 3 and 6, the enhanced corrosion resistance during the salt spray test by the addition of $\mathrm{Zn}$ is thought to be closely associated with the higher volume fraction and more continuous manner of grain boundary $\mathrm{Mg}-\mathrm{Zn}-\mathrm{Nd}-\mathrm{Gd}$ compounds resulting from grain refinement. 


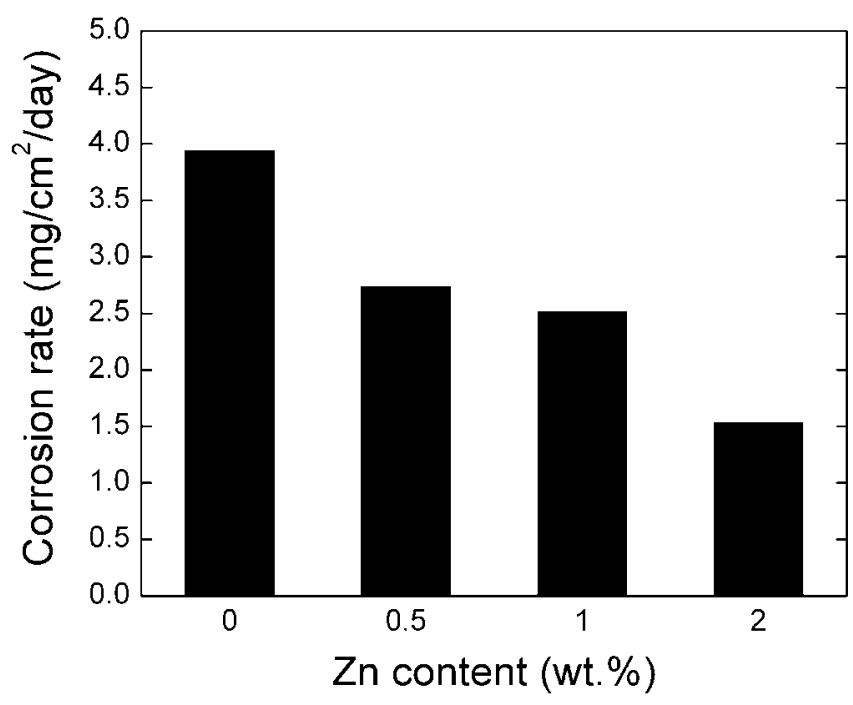

Fig. 5 Corrosion rates of peak-aged Mg-8\%Gd-2\%Nd-0.3\%Zr-(0 2)\%Zn alloys after salt spray test.

\subsubsection{Electrochemical corrosion test}

Figure 7 and Table 2 demonstrate the typical polarization curves and the values of $I_{\text {corr }}$ and $E_{\text {corr }}$ of $\mathrm{Mg}-8 \% \mathrm{Gd}-2 \% \mathrm{Nd}-$ $0.3 \% \mathrm{Zr}-(0 \sim 2) \% \mathrm{Zn}$ alloys. The polarization curves consist of cathodic and anodic reactions. The cathodic polarization curves are assumed to represent the cathodic hydrogen evolution through water reduction as reaction (1), while the anodic ones represent the dissolution of $\mathrm{Mg}$ as reaction (2): ${ }^{21}$ )

$$
\begin{aligned}
& 2 \mathrm{H}_{2} \mathrm{O}+2 \mathrm{e} \rightarrow \mathrm{H}_{2}+2 \mathrm{OH}^{-} \\
& \mathrm{Mg}-2 \mathrm{e} \rightarrow \mathrm{Mg}^{2+}
\end{aligned}
$$

The hydrogen evolution did not stop when the polarization potential increases to the anodic region due to the negative different effect (NDE). ${ }^{18)}$ On the other hand, it became even more intensive as the polarization potential increases to be more positive than the corrosion potential $\left(E_{\mathrm{corr}}\right)$. The values of $I_{\text {corr }}$ of investigated alloys are gradually decreased with increasing $\mathrm{Zn}$ content whereas the values of $E_{\text {corr }}$ are gradually increased. This result clearly indicates the enhanced corrosion resistance of the $\mathrm{Zn}$-containing alloys.

\section{Summary}

The peak hardness for $\mathrm{Mg}-8 \% \mathrm{Gd}-2 \% \mathrm{Nd}-0.3 \% \mathrm{Zr}$ alloys with different $\mathrm{Zn}$ contents can be obtained through isothermal aging at $220^{\circ} \mathrm{C}$ and the aging response time for the peak hardness is substantially reduced as the $\mathrm{Zn}$ content is increased.

The corrosion rate calculated by the salt spray test gradually decreases with increasing $\mathrm{Zn}$ content presumably because the precipitated compounds along the grain boundaries act as the corrosion barrier. In electrochemical corrosion tests the values of $I_{\text {corr }}$ are gradually decreased with increasing $\mathrm{Zn}$ content whereas the values of $E_{\text {corr }}$ are gradually increased, implying that the corrosion resistance is improved by $\mathrm{Zn}$ addition.
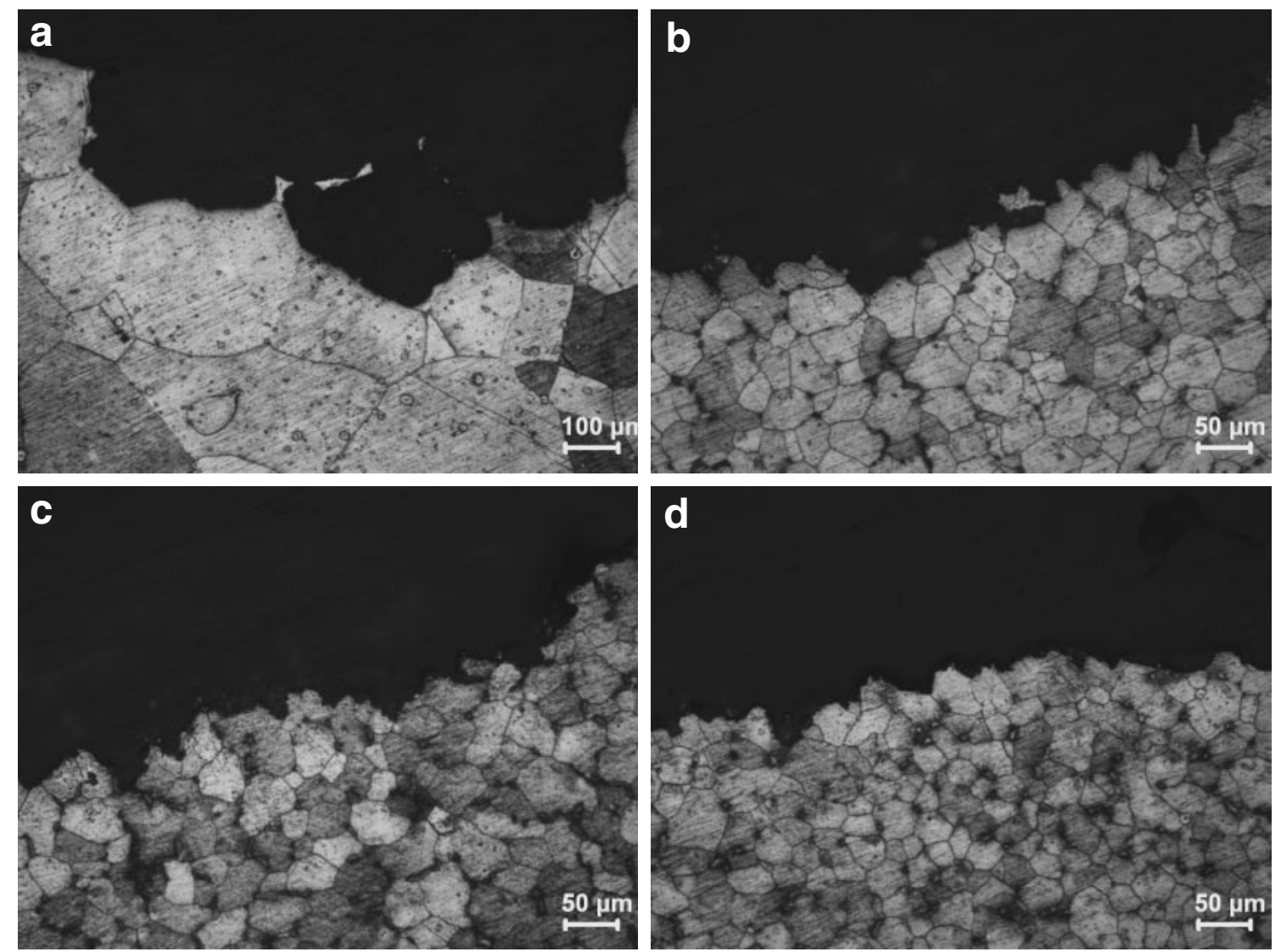

Fig. 6 Cross-sectional microstructures of the corroded surface after salt spray test for peak-aged (a) $\mathrm{Mg}-8 \% \mathrm{Gd}-2 \% \mathrm{Nd}-0.3 \% \mathrm{Zr}$, (b) $\mathrm{Mg}$ $8 \% \mathrm{Gd}-2 \% \mathrm{Nd}-0.3 \% \mathrm{Zr}-0.5 \% \mathrm{Zn}$, (c) Mg-8\%Gd-2\%Nd-0.3\%Zr-1\%Zn and (d) Mg-8\%Gd-2\%Nd-0.3\%Zr-2\%Zn alloys. 


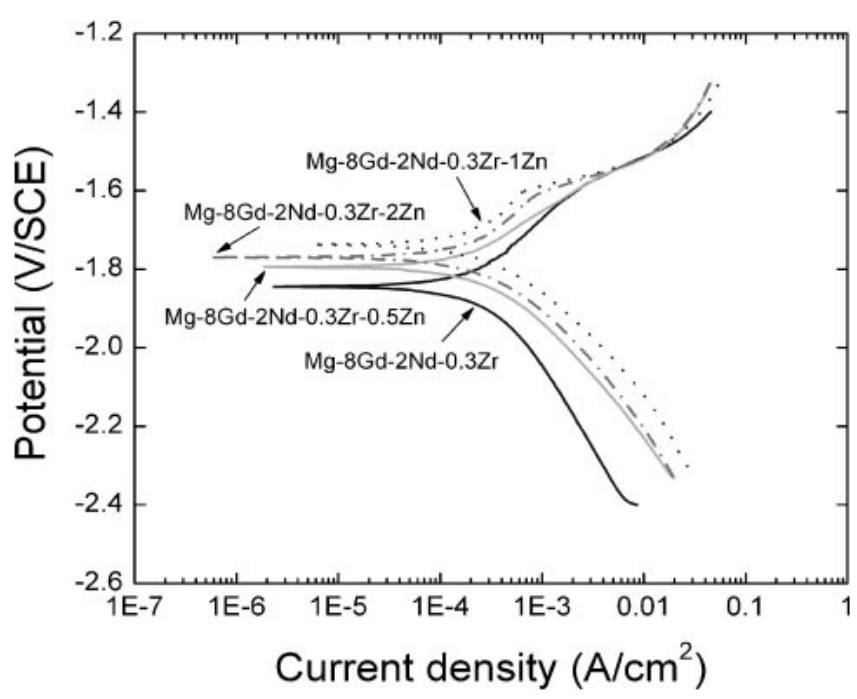

Fig. 7 Typical polarization curves of peak-aged $\mathrm{Mg}-8 \% \mathrm{Gd}-2 \% \mathrm{Nd}-$ $0.3 \% \mathrm{Zr}-(0 \sim 2) \% \mathrm{Zn}$ alloys.

Table 2 Values of $I_{\text {corr }}$ and $E_{\text {corr }}$ of peak-aged $\mathrm{Mg}-8 \% \mathrm{Gd}-2 \% \mathrm{Nd}-0.3 \% \mathrm{Zr}-$ (0 2)\%Zn alloys.

\begin{tabular}{ccc}
\hline Alloys & $I_{\text {corr }}\left(\times 10^{-5} \mathrm{~A} / \mathrm{cm}^{2}\right)$ & $E_{\text {corr }}(\mathrm{V})$ \\
\hline Mg-8\%Gd-2\%Nd-0.3\%Zr & 3.43 & -1.84 \\
\hline $\mathrm{Mg}-8 \% \mathrm{Gd}-2 \% \mathrm{Nd}-0.3 \% \mathrm{Zr}-0.5 \% \mathrm{Zn}$ & 2.95 & -1.79 \\
\hline $\mathrm{Mg}-8 \% \mathrm{Gd}-2 \% \mathrm{Nd}-0.3 \% \mathrm{Zr}-1 \% \mathrm{Zn}$ & 2.62 & -1.76 \\
\hline $\mathrm{Mg}-8 \% \mathrm{Gd}-2 \% \mathrm{Nd}-0.3 \% \mathrm{Zr}-2 \% \mathrm{Zn}$ & 1.35 & -1.73 \\
\hline
\end{tabular}

\section{REFERENCES}

1) C. Sanchez, G. Nussbaum, P. Azavant and H. Octor: Mater. Sci. Eng. A 221 (1996) 48.

2) I. J. Polmear: Mater. Sci. Technol. 10 (1994) 1-16.

3) G. Song and D. StJohn: J. of Light Metals 2 (2002) 1-16.

4) T. Honma, T. Ohkubo, K. Hono and S. Kamado: Mater. Sci. Eng. A 395 (2005) 301-306.

5) B. Smola, I. Stulíková, F. V. Buch and B. L. Mordike: Mater. Sci. Eng. A 324 (2002) 113-117.

6) B. L. Mordike: Mater. Sci. Eng. A 324 (2002) 103-112.

7) I. Anthony, S. Kamado and Y. Kojima: Mater. Trans. 42 (2001) 1206.

8) I. Nakatsugawa, S. Kamado, Y. Kojima, R. Ninomiya and K. Kubota: Corrs. Rev. 16 (1998) 139.

9) J. D. Hanawalt, C. E. Nelson and J. A. Peloubet: Trans. AIME 147 (1942) 273

10) M. Kiryuu, H. Okumura, S. Kamado, Y. Kojima, R. Ninomiya and I. Nakatsugawa: J. Jap. Inst. Light metals 46 (1996) 39.

11) J. F. Nie, X. Gao and S. M. Thu: Scr. Mater. 53 (2005) 1049-1053.

12) T. T. Sasaki, K. Oh-ishi, T. Ohkubo and K. Hono: Scr. Mater. 55 (2006) 251-254.

13) G. B. Hamu, D. Eliezer, K. S. Shin and S. Cohen: J. Alloy. Compd. 431 (2007) 269.

14) S. M. He, X. Q. Zeng, L. M. Peng, X. Gao, J. F. Nie and W. J. Ding: J. Alloy. Compd. 421 (2006) 309.

15) T. Honma, T. Ohkubo, S. Kamado and K. Hono: Acta Mater. 55 (2007) 4137.

16) G. Song, A. Atrens, D. St. John and J. Nairn, Y. Li: Corr. Sci. 39 (1997) 855.

17) J. H. Nordlien, K. Nisancioglu, S. Ono and N. Masuko: J. Electochem. Soc. 144 (1997) 461.

18) G. Song and A. Atrens: Adv. Eng. Mat. 5 (2003) 837.

19) C. L. Mendis, C. J. Bettles, M. A. Gibson and C. R. Hutchinson: Mater. Sci. Eng. A 435 (2006) 163-171.

20) T. Homma, T. Ohkubo, S. Kamado and K. Hono: Acta Mater. 55 (2007) 4137-4150.

21) G. Song and A. Atrens: Adv. Eng. Mat. 1 (1999) 11-33. 